\title{
Relationship between Bilingual Environment and Indonesian Language Development in Children
}

\author{
$1^{\text {st }}$ Dwi Herawati Ritonga \\ Department of Child Health \\ Faculty of Medicine \\ Universitas Sumatera Utara \\ Medan, Indonesia \\ dwiherawatiritonga@gmail.com
}

\author{
$2^{\text {nd }}$ Sri Sofyani \\ Department of Child Health, \\ Faculty of Medicine \\ Universitas Sumatera Utara \\ Medan, Indonesia \\ srisofyani@yahoo.com
}

\author{
$3^{\text {rd }}$ Lily Irsa \\ Department of Child Health, \\ Faculty of Medicine \\ Universitas Sumatera Utara \\ Medan, Indonesia \\ lilyirsa@yahool.com
}

\begin{abstract}
Language development is one of the most important developments in children, influenced by internal and external factors. One of the most influential external factors is verbal environment. Specific language disorder can occur in one language in children with bilingual environment in the first three years of life. A cross sectional study to assess relationship between bilingual environment and Indonesian language development in children was conducted in early childhood education programs in Medan, Indonesia from November 2017 to March 2018. All sample were recruited with consecutive sampling method. Physical and hearing examination were performed. Language development were examined with Cognitive Adaptive Test/ Clinical Linguistic Auditory Milestone Scale (CAT/CLAMS). Fisher's exact test was used to assess relationship between bilingual environment and Indonesian language development. There was $9.1 \%$ children with Indonesia language development disorder in bilingual group, whereas none in non bilingual group. There was significant relationship between bilingual environment and Indonesian language development in children.
\end{abstract}

Keywords-bilingual environment, Indonesian language development, children

\section{INTRODUCTION}

To enhance the physical development of children according to his age that needed the proper nutrition and food safety to be consumed by the child. The World Health Organization (WHO) emphasizes that food safety is an act to ensure all foods are safe for consumption [1]. In this case, it includes how to protect kids from choking hazards [2]. According to WHO, there are 1.5 billion cases of diarrhea worldwide (except in China), estimated at $70 \%$ relating to food consumption and a related 1.8 million deaths in children under the age of five [1].

In Indonesia, more than $40 \%$ of foodborne diseases are in children under five years [3]. In line with data cases of foodborne illness in early childhood children at kindergarten and preschool located in Petompon area in 2017 showed that 167 cases of influenza, 3 cases of vomiting and diarrhea and 2 cases of inflammation. Foodborne disease cases occur from exposures outside the home and home. Currently, research in Indonesia still focuses on food prepared outside of the home, while relating to food safety in home is still limited.
The factors influencing food safety are pollution caused by microorganisms such as bacteria, chemicals in food on certain food processing, and physical contaminants include dirt, hair, nail polish flakes, insects, broken glass, nails, staples, plastic,dust, flies. In under developed countries, food poisoning is caused by unhygienic conditions, lack of hygiene education, drought, contaminated water, improper food storage conditions, pesticide residues, dirty environment and improperly maintained [4].

Based on the above statement, food safety related to knowledge and behavior. The results of a 2000 Home Food Safety Study conducted by Audits Internationals that food safety mistakes are caused by $40 \%$ lack of knowledge, $40 \%$ lack of awareness and $20 \%$ lack of motivation [5]. In addition, the results of research by [6] indicate that knowledge and practice of food safety in housewives in Yogyakarta city is low. A recent review also implicates a lack of food preparation knowledge as barriers to prepare home cooked-meals [7]. The Health Belief Model also supports the above research results. This theory suggests that knowledge influences trust to vulnerability and severity of disease, benefits and barriers to practicing preventive health behaviors, and self-efficacy [8].

In many families, mothers have main responsibility for feeding children[9]. The child will learn to observe from the mother and putting knowledge into practice to prevent unsafe food [5].

The effort to increase food safety awareness for mother is educational methods. This methods aim for understanding and changing behavior. Educational methods which effectively to coach the mothers are film and discussion. The methods are more effective in giving awareness to change the behavior[10]. Based on an example or model, a person receives knowledge about the proper behavior as well as a guide in behaving [11]. Behavior is defined as everything that a person does or says. Behavior can be attributed to activities, actions, performance, responses, responses and reactions. Technically, behavior is related to muscle function, gland, human body electrical activity [12]. In this case the behavior is all the practices done by someone in the form of words and actions. Characteristics of behavior that can be measured through behavioral 
dimensions are frequency and duration [12].In addition, the habits can be formed after 66 days[13].

\section{MATERIALS AND METHODS}

This study is a cross-sectional study of two populations to assess the bilingual environment relationship and Indonesian language development in 18 - 36 months age children. This study was conducted in bilingual playgroup and Early Childhood Education institutions in Medan, Indonesia on November 2017 - March 2018. Target population are children aged 18 - 36 months in Medan. Sample is target population that meets the inclusion criteria chosen by consecutive sampling, divided into two groups, bilingual environment and non bilingual environment group (50 children each group). The inclusion criteria in this study are $18-36$ months age children lived in Medan, born full term with birth weight $\geq 2500$ grams. The exclusion criteria in this study are: 18 - 36 month age children who have cognitive and perceptual disorders, brain development disorders, hearing impairment, family and history of developmental language disorders. Consent was requested from parents after an explanation of the procedure. This study was approved by the Research Ethics Committee of the Faculty of Medicine, Universitas Sumatera Utara.

\section{A. Variables and Operational Definition}

The dependent variable is Indonesian language development, while the independent variable is the bilingual environment with the confounding variables are television exposure, the number of children in the family and maternal education level.

- The child is said to be in a bilingual environment when exposed to two languages from birth or use two languages in daily life, where one of those languages is Indonesian.

- Indonesian language development was assessed with cognitive Adaptive Test/Clinical Linguistic Auditory Milestone Scale (CAT/CLAMS). Indonesia language development disorder was declared if DQ CLAMS $\leq 85$ and DQ CAT > 85 from CAT/CLAMS assessment.

- Television exposure is the total amount of time children spend watching television per day. The total amount of time is divided into $\leq 2$ hours per day and $>2$ hours per day, regardless of the type and name of the television program.

- Number of children is the number of living children living with the family. Categorized into two groups, ie small family ( $<3$ children) and large family $(\geq 3$ children).

- Maternal education is the length of mothers receiving formal education, from elementary school to university. Categorized into three levels, ie low education level if only ever get a formal education for 6 - 11 years, moderate education level when getting a formal education for 12-13 years, high education level if getting formal education for 14 years or more.

\section{B. Procedures}

Explanation of the research objectives, the research flow, and the examination was given to the parents of the research sample. All samples were divided into two groups: bilingual environment group and non-bilingual environment group. Anamnesis was performed to obtain initial data of identity ie name, age / date of birth, sex, address and telephone number that can be contacted, name of parent / guardian, language used in daily life, birth history, family history of developmental disorder, the number of children, the total time of television exposure in children and the maternal education level. Physical examination, assessment of nutritional status and neurological examination were performed. The assessment of hearing impairment was performed with Tes Daya Dengar (TDD) instrument. The presence or absence of cognitive impairment in children was assessed by using Caput Scales Cognitive Adaptive Test (CAT). Followed by an assessment of language skills by using Clinical Linguistic Auditory Milestone Scale (CLAMS).

\section{Data Analysis}

Data analysis using fisher's exact test to see whether there is a relationship between bilingual environment and Indonesian language development. The relationship between dependent variable with the other confounding variables was also analyzed by using the fisher's exact test. The relationship of language development with bilingual environment and other confounding variables is expressed in the value of Prevalence Ratio (PR) with significance level $\mathrm{p}<0.05$.

\section{RESULTS AND DISCUSSION}

TABLE I. SAMPLE CHARACTERISTICS

\begin{tabular}{|c|c|c|}
\hline \multirow[b]{2}{*}{ Characteristics } & \multicolumn{2}{|c|}{ Bilingual Environment } \\
\hline & $\begin{array}{c}\text { Yes } \\
(n=55)\end{array}$ & $\begin{array}{c}N o \\
(n=55)\end{array}$ \\
\hline Gender, $\mathrm{n}(\%)$ & & \\
\hline Boy & $28(50.9)$ & $27(49.1)$ \\
\hline Girl & $27(49.1)$ & $28(50.9)$ \\
\hline Body weight $(\mathrm{kg})$ & & \\
\hline Interval & $12-16$ & $12-16.8$ \\
\hline Mean & 13.9 & 14 \\
\hline Median & 14 & 14 \\
\hline Body height $(\mathrm{cm})$ & & \\
\hline Interval & $85-104$ & $85-105$ \\
\hline Mean & 95.1 & 95.3 \\
\hline Median & 95 & 95 \\
\hline Age (months) & & \\
\hline Range & $24-36$ & $30-36$ \\
\hline Mean & 33 & 33.3 \\
\hline Median & 32 & 36 \\
\hline Maternal education level, $\mathrm{n}(\%)$ & & \\
\hline Moderate & $18(32.7)$ & $20(36.3)$ \\
\hline High & $37(67.2)$ & $35(63.6)$ \\
\hline Number of children, $\mathrm{n}(\%)$ & & \\
\hline Small family ( $<3$ children) & $49(89.1)$ & $48(87.2)$ \\
\hline Large family ( $\geq 3$ children) & $6(10.9)$ & $7(12.7)$ \\
\hline Television exposure, $\mathrm{n}(\%)$ & & \\
\hline$\leq 2$ hours & $33(60)$ & $26(47.3)$ \\
\hline$>2$ hours & $22(40)$ & $29(52.7)$ \\
\hline
\end{tabular}


A Total sample of 11018 - 36 month age children, divided into two groups: bilingual and non-bilingual environment, 55 children in bilingual environment group and 55 children in non-bilingual environment group. Characteristics of all sample are listed on Table 1.

In this study there was no difference between DQ CAT and DQ CLAMS values in children in bilingual environment and children in non-bilingual environment (table 2), there are none of children with cognitive impairment based on the DQ CAT values.

Table 3 is a bivariate test (fisher's exact test) between Indonesian language development and bilingual environment. The independent variable, bilingual environment has relationship with Indonesian language development as dependent variable. There was $9.1 \%$ of children with Indonesia language development disorder in bilingual group, otherwise there is none in non-bilingual environment group, with $\mathrm{p}<$ 0.05 .

TABLE II. COMPARISON OF DQ CAT AND DQ CLAMS VALUES BETWEEN GROUPS

\begin{tabular}{|c|c|c|c|}
\hline \multirow[b]{2}{*}{ Paramateres } & \multicolumn{2}{|c|}{ Bilingual environment } & \multirow[b]{2}{*}{$\boldsymbol{P}$} \\
\hline & $\begin{array}{c}\text { Yes } \\
(n=55)\end{array}$ & $\begin{array}{c}N o \\
(n=55)\end{array}$ & \\
\hline DQ CAT $^{\mathrm{a}}$ & $99.4(86-117.14)$ & $99.4(88-117.14)$ & 0.31 \\
\hline DQ CLAMS $^{\mathrm{b}}$ & $102.04(\mathrm{SD} \pm 11.68)$ & $103.87(\mathrm{SD} \pm 9.29)$ & 0.36 \\
\hline
\end{tabular}

TABLE III. BIVARIATE ANALYSIS (FISHER'S EXACT) BETWEEN BILINGUALENVIRONMENT AND INDONESIA LANGUAGE DEVELOPMENT

\begin{tabular}{|c|c|c|c|c|c|}
\hline \multirow{2}{*}{ Variable } & \multicolumn{2}{|c|}{$\begin{array}{c}\text { Indonesian language } \\
\text { development }\end{array}$} & P & PR & $\begin{array}{c}\mathbf{9 5 \%} \\
\text { CI }\end{array}$ \\
\cline { 2 - 5 } & Normal & Disorden & & & \\
\hline $\begin{array}{c}\text { Bilingual environment } \\
\text { (n \%) }\end{array}$ & & & & \\
Yes & $50(90.9)$ & $\begin{array}{c}5(9.1) \\
\text { No }\end{array}$ & $0.03^{\mathrm{a}}$ & 1.1 & $\begin{array}{l}1.01- \\
1.20\end{array}$ \\
\hline
\end{tabular}

TABLE IV. BIVARIATE ANALYSIS (UJI FISHER 'S EXACT) BETWEEN INDONESIA LANGUAGE DEVELOPMENT AND CONFOUNDING VARIABLES

\begin{tabular}{|c|c|c|c|c|}
\hline \multirow{2}{*}{ Variables } & \multicolumn{2}{|c|}{$\begin{array}{r}\text { Indonesia language } \\
\text { development }\end{array}$} & \multirow[t]{2}{*}{$P$} & \multirow[t]{2}{*}{ PR $(95 \% \mathrm{CI})$} \\
\hline & $\begin{array}{l}\text { Normal } \\
(\mathrm{n}=50)\end{array}$ & $\begin{array}{l}\text { Disorder } \\
(\mathrm{n}=5)\end{array}$ & & \\
\hline \multicolumn{5}{|l|}{ Television exposure, n(\%) } \\
\hline $\begin{array}{l}\leq 2 \text { hours } \\
>2 \text { hours }\end{array}$ & $\begin{array}{l}33(100) \\
17(77.3)\end{array}$ & $\begin{array}{l}0(0) \\
5(22.7)\end{array}$ & 0.08 & $0.77(0.61-0.97)$ \\
\hline \multicolumn{5}{|l|}{ Number of children, $n(\%)$} \\
\hline $\begin{array}{l}\text { Small family ( }<3 \text { children }) \\
\text { Large family }(\geq 3 \text { children) }\end{array}$ & $\begin{array}{l}45(91.8) \\
5(83.3)\end{array}$ & $\begin{array}{l}4(8.2) \\
1(16.7)\end{array}$ & 0.45 & $2.04(0.27-15.4)$ \\
\hline \multicolumn{5}{|l|}{ Maternal education level, n(\%) } \\
\hline $\begin{array}{l}\text { Moderate } \\
\text { High }\end{array}$ & $\begin{array}{l}18(100) \\
32(86.4)\end{array}$ & $\begin{array}{l}0(0) \\
5(13.6)\end{array}$ & 0.12 & $1.15(1.01-1.31)$ \\
\hline
\end{tabular}

Table 4 is a bivariate test (fisher's exact test) between confounding variables ie television exposure, number of children and education level of mothers with dependent variable Indonesian language development. There was no statistically significant relationship between the dependent variable and confounding variables

Language is an important part of life. With the language of one individual with another individual will be interconnected through the process of language [6]. Bilingual environment issues need to be considered in the linguistic process used by a society. The experience of two or more languages at an early age is different from the experience of one language [2].

The identification of two languages simultaneously to the child is called simultaneous bilingual, where the child is introduced in two languages from birth so that the child can master both languages simultaneously. Children who learn a second language after beginning to master the first language are called sequential bilinguals, where children usually learn from interactions with native speakers of the language that exist in the surrounding community or by teachers at school [79]. The study was conducted in several Early Childhood Education institutions that are bilingual based and not bilingual based. All children enrolled in bilingual-based early childhood institutions in this study were bilingual sequential children.

The study of relationship between bilingual environment and children is distinguished over the period before 1960 and after 1960. Studies of the period prior to 1960 tend to argue that bilingual environment negatively affect cognitive and intelligence, whereas post-1960 studies show bilingual environment overcome monolingual appearances in both cognitive and in academic performance [2]. In this study, there was no significant difference between cognitive in children with bilingual environment and children with monolingual environment ( $\mathrm{p}$ 0.31). It was shown from the DQ CAT of each group, where for the bilingual environment DQ CAT $=99.4$ $(86-117.14)$ and for the monolingual environment DQ CAT $=$ $99.4(88-117.14)$.

Language developmental disorders in children with a bilingual environment occur similarly in children with a monolingual environment. In a 1997 US study of 7\% of children with bilingual environment experienced impaired language development [5]. This suggests that the bilingual environment does not necessarily cause language development disorders, but is also influenced by other factors that also affect children in the monolingual environment [3,5]. From this study, the prevalence of children experiencing Indonesia language development disorder in bilingual environment was $9.1 \%$, whereas none in non-bilingual environment.

A systematic review comparing language development in bilingual and monolingual groups in which one language is English derives different results. Three studies showed a negative bilingual environmental impact on the development of English as a second language compared with monolingual children, three studies showed no differences in language development, three studies showed a negative impact only on one language, and one study showed a positive impact on the development of the child's language by bilingual environment [4]. The first study of bilingual Spanish - English children aged 
3 - 4 years in the United States in 2008 showed the use of disturbed English consonants compared to monolingual children [10]. The second study compares the phonemic development of language between British monolingual children, Spanish and bilingual Spanish-British monolinguals. Children in Spanish-English bilingual environments have phonemic language development disturbance compared to children with a monolingual environment for each language [11]. The third study in 2010 comparing children to SpanishBritish bilingual environments, British monolinguals and Spanish monolinguals aged 3 - 4 years showed a lower level of English accuracy in bilingual groups [12].

This is similar to our result, where in the bilingual environment there are children who experience developmental disorders of the Indonesian language based on the results of screening screening of Indonesian language development CAT / CLAMS. In this study, the possibility of Indonesia language disorder in bilingual environment 1.1 times greater than non

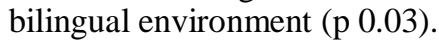

The bilingual environment as one of the environmental factors that influence the development of language also interacts with other factors, namely the level of mother education, the number of children in the family, and television exposure [2]. In this study, other factors have no significant relationship with Indonesia language development in children with bilingual environment. Our results showed that in bilingual environment group, children with large family (number of children $\geq 3$ ) have 2.04 times greater risk than children with small family (number of children <3) for developing Indonesia language disorder ( $p$ 0.45). This is different from previous studies in the United States of 2012, where it is said that large family (number of children $\geq 3$ ) can significantly decrease the receptive language of the child ( $\mathrm{p}$ 0.02) [13].

Previous study has shown that maternal education has a significant relationship with the development of language in children, where mothers with high and middle education tend to have children with more vocabulary [13]. The language ability of parents with a high level of education will be different from lower levels of education, so it will be more suitable as a linguistic model in children. In this study, we only found moderate and high maternal education level in both groups of children $[14,15]$. It is inversely proportional to previous study, high maternal education level becomes a risk factor for the development of Indonesia language disorder in children with bilingual environment. Bilingual children with mothers who have a high education level 1.15 times for developing Indonesia language disorder compared with mothers who have moderate education level ( $\mathrm{p} 0.12$ ).

Watching television in children under three is a factor that makes children more as passive listeners. In a certain period of time, the brain should get a lot of stimulation from the environment for providing feedback, but because the more stimulation is the television, the development of brain cells that play role in language and speech will be hampered [16]. In this study there was no statistically significant relationship between television exposure and Indonesian language development in children with bilingual environment ( $\mathrm{p}$ 0.08). But from the data, all children with Indonesian language development disorder in bilingual environment has television exposure $>2$ hours per-day. Television exposure $\leq 2$ hours is a protective factor which is children in bilingual environment with television exposure $\leq 2$ hours have 1.3 times lower risk for having Indonesian language development disorder. This supports previous studies, where in children younger than two years with high television exposure will experience delays in expressive language. Similarly, children younger than one year with high television exposure and no companions have a significant risk of having language delays. The American Academy of Pediatrics (AAP) recommends that children watch television for no more than two hours per day, especially for children under two years of age $[16,17]$.

\section{CONCLUSION}

There is a significant relationship between bilingual environment and Indonesian language development in children, but there is no significant relationship between television exposure, the number of children and the maternal education level with the Indonesia language development in children

\section{REFERENCES}

[1] Soetjiningsih, Faktor-Faktor yang Mempengaruhi Tumbuh Kembang. In: Soetjiningsih, and I.G.N.G. Ranuh Editors. Tumbuh Kembang Anak. Edisi ke-dua. Jakarta: Penerbit Buku EGC, 2013.

[2] R.N. Indah, "Language acquisition process: from ability to lack of language skills,” IEEE Transl. LiNgua, vol. 3, pp. 1-9, 2008.

[3] K. Kohnert, "Bilingual children with primary language impairment: issues, evidence and implications for clinical actions," $\mathrm{J}$ Commun Disord, vol. 43, pp. 456-73, 2010.

[4] H. Hambly, Y. Wren, S. McLeod, and S. Roulstone, "The influence of bilingualism on speech production: A systematic review," Int J Lang Commun Disord, vol. 48, pp. 1-24, 2013.

[5] J.B. Tomblin, N.L. Records, P. Buckwalter, X. Zhang, E. Smith, and M. O'Brien, "Prevalence of specific language impairment in kindergarten children," Journal of Speech, Language, and Hearing Research, vol. 40, pp. 1245-60, 1997.

[6] K. Sudrama, and I.B.P. Yadnya, "Dilemma of multilingualism and its implications for language planning," IEEE Tranls. Jurnal Ilmu Bahasa, vol. 1, pp. 94-107, 2015.

[7] National Research Council and Institute of Medicine, Improving Schooling for Language-Minority Children: A Research Agenda. Washington DC: National Academy Press, 1997.

[8] L. Pettito, M. Katerelos, B. Levy, K. Gauna, K. Tétreault, and V. Ferraro, "Bilingual signed and spoken language acquisition from birth: Implications for the mechanisms underlying early bilingual language acquisition," Journal of child Language, vol. 28, pp. 453-496, 2001.

[9] L.A. Petitto, and S. Holowka, "Evaluating attributions of delay and confusion in young bilinguals: special insights from infants acquiring a signed and spoken language," Sign Language Studies, vol. 3, pp. 4-33, 2002.

[10] C.E. Gildersleeve-neumann, E.S. Keste, and B.L. Davis, "English sound development in preschool-aged children from bilingual English-Spanish environments," Language, Speech, and Hearing Services in Schools, vol. 39, no. 314, 2008.

[11] F. Bunta, L. Fabiano-smith, B.A. Goldstein, and D. Ingram, "Phonological whole-word measure 3-year-old bilingual children and their age-matched monolingual peers," Clinical Linguistics and Phonetics, vol. 23, no. 2, pp. 156-175, 2009.

[12] L. Fabiano-smith, and B.A. Goldstein, "Phonological acquisition in bilingual Spanish-English speaking children," Journal of Speech, Language and Hearing Research, vol. 53, no. 1, pp. 160-178, 2010. 
[13] H. Prime, S. Pauker, A. Plamondon, M. Perlman, and J. Jenkin, "Sibship size, sibling cognitive sensitivity, and children's receptive vocabulary," Pediatrics, vol. 133, no. 2, 2014.

[14] M.H. Bornstein, C.S. Hahn, J.T.D. Suwalsky, and O.M. Haynes, SocioEconomic Status, Parenting and Child Development: The Hollingshead Four-Factor Index of Social Status and the Socio-economic Index of Occupations. In: M.H. Bornstein, and R.H. Bradely, Editors. Socioeconomic Status, Parenting and Child Development. New Jersey: Lawrence Erlbaum; 2003.
[15] S. Butler, C. McMahon, and J.A. Ungerer, "Maternal speech style with paralinguistic twin infants," Infant and Child Development, vol. 12, no. 2, pp. 129-43, 2003.

[16] M. Krcmar, B. Grela, and K. Lin, "Can toddlers learn vocabulary from television? An experimental approach," Media Psychol, vol. 10, pp. 4163, 2007.

[17] American Academy of Pediatrics Comitte on Publication Education, "Children adolescents, and television," Pediatrics, vol. 107, pp. 423-6, 2001. 